University of Chicago Law School

Chicago Unbound

Journal Articles

Faculty Scholarship

1938

\title{
Handbook of the Law of Wills and Administration of Decedents' Estates, Including Principles of Intestate Succession
}

Max Rheinstein

Follow this and additional works at: https://chicagounbound.uchicago.edu/journal_articles

Part of the Law Commons

\section{Recommended Citation}

Max Rheinstein, "Handbook of the Law of Wills and Administration of Decedents' Estates, Including Principles of Intestate Succession," 5 University of Chicago Law Review 537 (1938).

This Article is brought to you for free and open access by the Faculty Scholarship at Chicago Unbound. It has been accepted for inclusion in Journal Articles by an authorized administrator of Chicago Unbound. For more information, please contact unbound@law.uchicago.edu. 
Handbook of the Law of Wills and Administration of Decedent's Estates, Including Principles of Intestate Succession. By Thomas E. Atkinson. St. Paul: West Publishing Co., I937. Pp. xiv, 916. \$5.00.

This book has a short title and a long sub-title. The latter appears necessary to indicate that the former denominates but a part of the field covered by Professor Atkinson's book and by the usual law school course on "Wills." The prominence of that part is indicative, however, of the emphasis laid upon it in the traditional treatment of the field, a field which might appropriately be called "law of inheritance" or "law of decedents' estates." The practicing lawyer has to deal with it primarily when he is drafting a will for a client, when he undertakes to attack a will or to have an unclear will interpreted, or when he is engaged in the administration of a decedent's estate. A law school bent on vocational training of students for legal practice will offer them a course where students can learn the rules and, as far as possible, the techniques of the art of testamentary draftsmanship, and of administering decedents' estates. American law schools being traditionally uninterested in statute law, administration with its multitude of minute statutory provisions and its marked jurisdictional differences has been pushed into the background, and wills have been so emphasized as to lend their name to the entire course and the entire field. Not all the law, however, that the testamentary draftsman ought to know has been treated in the course on Wills. Trusts and Future Interests have been elevated to the dignity of separate branches of the law, of separate courses, and of separate texts, case-books, and restatements. Recent law-school developments reveal two trends: either to combine in one course, and one book, all the legal information needed by the testamentary draftsman, combined with the complete elimination of administration of estates from the curriculum; or to change the approach entirely and to attack the field of succession in its entirety, no longer under the aspect of the immediate needs of the testamentary draftsman but of governmental policy. This latter approach must, of course, be followed by any law school which proclaims as its aim "the training of the law men of the future-judges, legislators, and administrators, as well as advocates and counsellors."'r

A course or a book devised on such lines will have to start out with an inquiry into the social function of the law of inheritance in general, which will appear as the preservative of peace through establishing a system of rules by which every asset left behind by a dead man is assigned as "his" to some definite individual. How shall these individuals be determined? Shall the decedent have the power to determine those individuals which shall be recognized after his death as the "lawfully entitled" to his assets? Shall there be limits to such power, and if so, what limits? By what policies are those limits determined? What limits have actually been established by American legislatures and courts? Why? Are there any reasons for providing that the power shall be exercised only under certain formalities? What formalities have been established by American legislatures and courts, and by law-makers in other countries? Do these requirements fulfill the purposes for which they have been established? What difficulties do lawyers and judges encounter in their efforts to follow, or to evade, these requirements?

What shall be done with the assets left by a dead person who has not, or who has not properly, availed himself of the power of determination granted to him by the

× See Katz, A Four-Year Program for Legal Education, 4 Univ. Chi. L. Rev. 527, 534 (I937). 
legal order? What rules have actually been established in the United States with respect to the distribution of such assets? How shall a legislature formulate such rules in order to make them understandable, unambiguous, and workable (problems of legislative draftsmanship)?

Assuming that certain formalities are prescribed for transactions determining the fate of a person's assets after his death, and that no such formalities are prescribed for transactions by which a person determines the fate of certain of his assets during his lifetime, what policies determine the classification of transactions of a mixed character?

When such and similar questions are asked, the law of "wills" appears as a set of rules designed to carry out certain governmental policies. The rules become understandable, and their interrelations among each other and with other rules of law become apparent. A structure will be recognized in which certain policies and rales appear as the foundations and main pillars, and others as detail, either conditioned by the main structure, or serving merely ornamental purposes.

The field of administration can be treated in the same way: Again in the interest of public peace, the state must establish some machinery for the orderly transfer of property from the dead to the living, and-particularly important in a society built on credit-for the proper payment of the dead man's debts. What types of machinery have been designed for that purpose by human ingenuity? What machinery has been designed in particular in America? What are the main lines of its structure? How does it function? Could it be simplified, made more efficient, less expensive, or otherwise improved? What improvements have been made? In such fashion, the entire law of administration can again be reduced to a structural design, with all the main features showing up clearly, and the details fading into the background.

It is the great merit of Professor Atkinson's book that, in parts, at least, its author undertakes such a functional analysis of the rules and institutions of the law of inheritance. However, the book has not been consciously and consistently conceived in that method. Large parts read like old-fashioned textbooks of the "vertical digest type." Others, however, are refreshingly vivid and incisive. Such chapters as those on incorporation by reference, on testamentary witnesses, on "functions and necessity of administration" or on "presentment and allowance of claims" make the book valuable not only for law students but also for the harassed practitioner who, before or after delving into the shapeless masses of digest materials feels the need of having before his mind a clear picture of the conflict of interests and policies of which his individual case happens to be an illustration.

The book is a typical product of a period of transition, and its last chapter, i.e., that on interpretation of wills, is a typical illustration of its ambivalent character. A brief discussion of the basic problems which are presented to lawyers and courts under the label of interpretation is followed by a statement of traditional rules of interpretation, which, mostly based on Jarman, repeats traditional language of courts without much inquiry into their policies. This section, in turn, is followed by a brief chapter "Suggestions Regarding Drafting of Wills" which, based on rich experience, will be valuable for the practitioner as well as for the student. The least satisfactory chapter is that on the "History of Wills" which fails not only to grasp the field of inheritance in its entirety, but also to connect the various disconnected data of Egyptian, Assyrian, Jewish, Greek, and Roman civilizations with the main body of the 
book. However, in spite of such shortcomings, the book marks a step forward in the development of a new type of textbook. It is a useful handbook for the practicing attorney, and law teachers will welcome it and recommend it as collateral reading, especially on those topics which are but cursorily treated in the classroom.

Max Rheinstei**

False Security. By Bernard J. Reis. New York: Equinox Cooperative Press Inc., I937. Pp. xv, 362. \$2.75.

The author's thesis is that the issuers of securities, the originating and distributing bankers, the trustees under bond and debenture issues, the certified public accountants, the lawyers, and the reorganizers are all unethical if not studiously criminal; that legislatures and the courts, if not unethical and criminal are shortsighted and lax in their opportunities to protect the investing public. Consequently the average person, without knowledge of the facts, is duped and his savings evaporated through the purchase of worthless securities.

Chapters 2 to II contain histories of, and comments on, security issues, cases and practices variously taken from Congressional committee investigations, the Alger Report on the New York Insurance Department, the records of cases and the author's study of the Hearst preferred stock issue. The conclusions therefrom that securities purchasers have been swindled in many of the cases, that some participants in security issues have acted criminally, that some investment bankers deserve prison cells and many of them thorough suspicion, that some professional men are scoundrels, no one can question. But Mr. Reis does not stop there. His charges are wholesale, his condemnation unlimited, and consequently inaccurate.

The groups against whom Mr. Reis makes his charges need a rededication to fair dealing. Any polemic which pricks their conscience or puts fear of consequences in them serves a desirable purpose. To hope that security buyers can continue their blind purchasing of securities without dire consequences is folly whatever rejuvenated conscience may appear in said groups.

The author suggests as a remedy for the investing public the organization of a disinterested body of experts to serve as representatives of the security holders, make investigations of new issues, sanction protective legislation and disseminate such information periodically to the investors. Any such organization equipped to function intelligently will perforce need a large and constantly replenished reservoir of funds. That investors will pay the piper may well be doubted. Unquestionably, such an organization could render invaluable service to them. If one were inclined to be petty one might ask Mr. Reis if all the other human beings are dishonest at the jingle of the guinea, isn't it a bit credulous to expect the experts in the proposed organization to turn a deaf ear; and it will be interesting to see the "protective provisions" thrust upon members which will find a model in the trustee article of the trust indentures and the deposit agreements and agreements of reorganization managers (damned in Chapters 8 and 9 respectively). Despite such possibilities the proposed organization is not to be decried. Any help is worth while. One wonders, however, if there is any remedy for avarice or for ignorance. Neither biblical, canonical, common or statutory law can protect a fool from his folly. The investing public may learn that the cards are marked

* Max Pam Professor of Comparative Law, University of Chicago Law School. 